\title{
Working Poor in Mainland China: Concept and Life Trajectory of Its Main Working Groups
}

\author{
Jinghong Liu \\ Université Libre de Bruxelles, Brussels, Belgium
}

\begin{abstract}
In-work poverty seems to be a kind of "invisible poverty", which is closely related to the social risk and particularly lurks among working-age population. It de facto brings out the problematical aspects of economic and social secured conditions among individuals who are "in-work". In the labor market, describing and discussing the main working poor groups reveals the issue of in-work poverty. Based on this, working poor refer to the people who have a decent job but fall under the poverty threshold and have high risk into the condition of insecure and poor working/living quality. Internationally, the bulk of literature on in-work poverty comes from developed countries. However, the Asia-related research on in-work poverty remains underexplored. Thereby, the research describes a vivid picture of working poor in mainland China, makes a general definition and also, investigates that what kind of working groups in mainland China are suffering from high risk into poverty. The attempts will be made to distinguish the main in-work poverty groups with their trajectory historically under the labor market transformation and the economic reform. The research aims at a better understanding of poverty issue in the labor market underlying the life course and gender dimension.
\end{abstract}

Keywords: working poor, China, migrant workers, laid-off workers, gender, life course

The issue of working poor related to the labor market and social welfare is well documented in North America and Western Europe (Smith, Stenning, Rochovská, \& Świagtek, 2008), while it is a more recent and less researched phenomenon in the developed countries. Even in the China's academia, the working poor gained interest only in the late 2000s. Nevertheless, there is more than half of the world's labor force employed in Asia, and China by itself accounts for 1/4 of the world's labor force employed. Then notably, the issue of in-work poverty in China is a crucial topic that we cannot skirt it. Thereby, the study aims at a better understanding of in-work poverty by focusing on working poor groups in China's labor market. Closely linked to the aspects of labor market reconstruction and related welfare transition, in-work poverty lurks in some working groups, which refer to the people who have a decent job but still fall under the poverty threshold and have high risk into the condition of insecure and poor working/living quality.

\section{Working Poor in China}

In-work poverty happens among workers in the labor market, it thus forms working poor. In the research, we define working poor in China as the employed people who have an income below the World Bank poverty

Corresponding author: Jinghong Liu, $\mathrm{PhD}$ candidate, Université Libre de Bruxelles, Brussels, Belgium; research fields: gender study, working poor. 
standard (below \$3.1 per day) and have high risk into the condition of insecure and poor working/living quality. Thereby, working poor manifest as the characters of insufficient social and economic security.

Working poor not only refer to workers but also concern about their family. In detail, the above definition answers two fundamental questions: (1) Who is working? It refers to people who were employed at least half of the previous year (six months of a year), male aged at 16-60, and female aged at 16-55 in China; and (2) who is poor? It refers to people whose equivalent income fall below the national poverty line. It contains two criteria including two distinct measures: poverty and work. In the author's opinion, it has two important levels: individual level —in-work poverty for workers; household level—high risk into poverty for family (having at least one family work member). There are three kinds of working poor: the individuals with low pay, the individuals with low education or low skill (relatively low capability to obtain resources), and the individuals with relatively high needs (e.g. having a huge family to support).

Then, who are working poor in China? Until nowadays, there were no records of definition and population mapping for working poor in China. As the estimate of poverty in China is based on the living conditions of non-working households, and there is a wide belief that employment is enough to avoid poverty; the people who have jobs have usually been neglected into China's official poverty estimation since then. While, working poor indeed exist in China invisibly, and some researchers have found that working poor in China mainly include rural migrant workers, laid-off workers, newly university graduates with low income, single mothers, disabled people, and other low-income individuals with the heavy family burden (Yao, 2011). In China, working poor are individuals who are working for pay while living in poverty. Based on this, in order to map the general population of working poor, the population estimates are based on the poor individual standards.

Table 1

The Estimated Population of Working Poor in Mainland China

\begin{tabular}{|c|c|c|c|c|c|c|c|c|c|c|c|c|}
\hline \multirow[t]{2}{*}{ Unit: million } & \multicolumn{2}{|c|}{1990} & \multicolumn{2}{|c|}{1998} & \multicolumn{2}{|c|}{2011} & \multicolumn{2}{|c|}{2013} & \multicolumn{2}{|c|}{2014} & \multicolumn{2}{|c|}{2015} \\
\hline & WP L & WP U & WP L & WP U & WP L & WP U & WP L & WP U & WP L & WP U & WP L & WP U \\
\hline Total population & \multicolumn{2}{|c|}{1143.33} & \multicolumn{2}{|c|}{1247.61} & \multicolumn{2}{|c|}{1347.35} & \multicolumn{2}{|c|}{1360.72} & \multicolumn{2}{|c|}{1367.82} & \multicolumn{2}{|c|}{1374.62} \\
\hline Employment population & 650.5 & 862.5 & 710.6 & 747.5 & 764.20 & 1002.83 & 769.77 & 1005.82 & 772.53 & 1004.69 & 774.51 & 1003.61 \\
\hline $\begin{array}{l}\text { Poor population } \\
(3.1 \$ \text { per day-2011, 2013) }\end{array}$ & \multicolumn{2}{|r|}{ / } & \multicolumn{2}{|r|}{ l } & \multicolumn{2}{|c|}{299.38} & \multicolumn{2}{|c|}{151.04} & \multicolumn{2}{|c|}{88.97} & \multicolumn{2}{|c|}{72.83} \\
\hline Working poor & 191.3 & 240.5 & 131.5 & 143.7 & 169.80 & 222.83 & 85.44 & 111.64 & 50.25 & 65.35 & 41.04 & 53.17 \\
\hline
\end{tabular}

Notes. Source: Berger and Harasty calculated the Chinese working poor population of 1990 and 1998. Author calculation: Working poor of 2011, 2013, 2014, and 2015 were calculated according to NBSC (National Bureau of Statistics of China) and the World Bank. The total population and employment population come from China Statistical Yearbook (1998, 2015, and 2016). And the poor population of 2011 and 2013 was calculated according to the World Bank ( $\$ 3.1$ per day). The poor population in 2014 and 2015 was calculated according to national socio-economic development report in China $(2014,2015)$ by national poverty line.

Table 1 shows the estimated population of working poor in mainland China. Based on the poverty line (\$3.1 per day) in the World Bank, the population of working poor in China (2011) was calculated between 169.80 and 222.83 million. Until 2013, the estimated population of working poor has significantly decreased to 85.44-111.64 million. Based on the national poverty line, there were nearly 50.25-65.35 million people who are defined as working poor in the labor market in 2014. And these working groups with high risk into poverty declined gradually in 2015. Nevertheless, there are striking estimated 41.05-53.17 million working-age people with income below the poverty line, who have higher risk into poverty. 


\section{Poverty Transition in Chinese Mainland}

Poverty exists everywhere until nowadays, and it is widely concerned as a high-probability event often happening in the unemployed occasion. The poverty among workers in the labor market-their poor living conditions and related high risk into unsecured condition — raised little attention in academic and political dialogues. In fact, poverty also lurks in work person with relatively low pay, employed in flexible/temporary jobs or low-skilled/educated sectors. Research on working poor is a good perspective to rethink the relations among individual in society, labor market, and social security.

In the past, the ideology for a family as the primary social safety net was historically rooted in Chinese traditional social norms. Based on this, working poor were hindered in a conventional mutual-help system provided by family members (Jia ting hu zhu), and this is because that poverty issues (caused by unemployment, economic deprivation, divorce, etc.) were commonly regarded as an individual problem which should be solved prior based on power of family affairs (Jia wu shi). After following the flexibility in labor market reform (commonly primary trend in western countries and has arrived in China nowadays) and the changes of family compositions (nuclear family under the one-child policy before 2016, increased divorce rate, etc.), family support based on such traditional help network was not enough to avoid poverty in working population any more. Thus, working poor have been recently addressed since the 2010s. Moreover, the China's government has focused attention on anti-poverty to unemployed population and rural citizens in recent two decades, while the issue of in-work poverty has not yet been paid too much attention to the political making-decision level. Until nowadays, there are no official records for definition or detailed descriptions for main in-work poverty groups in China. In short, according to the national poverty line, China's absolute poverty is increasingly reducing, while the in-work poverty is gradually becoming more and more prominent nowadays.

According to the national poverty line, China's absolute poverty is increasingly reducing, while the in-work poverty is gradually becoming more and more prominent nowadays. Among working groups, in-work poverty is changeable and has different faces during each period; it may manifest as various characteristics by different working groups and generations. Being grown in the different historical period, people suffer their own feeling/understanding to the poverty. For instance, for people who were born in the 1960s and 1970s, most of them experienced the reform of state-owned enterprises in 1980s, and the poverty with material deprivation was standard focused. You cannot image the situation that a female labor worked hard and saved money every day but still could not make ends meet, because the salary was so low and there were not enough social servers to support a family, only by parents themselves. After that, members of families were facing the shock of state-owned enterprise reform and suffering from being laid-off. Then what is the poverty experience? For labors, it is the highly social risk of losing job and corresponding workfare. For families, poverty is the worries that to make sure if there is enough money to support children to go to school and make ends meet.

As for generations who were born in the late 1990s and grew in the 2000s, the poverty transformed. For the most part, material deprivation is no longer the crucial problem that was before. They enjoyed the fundamental social welfare for education, health, and some others, while poverty becomes synonymous with "inequality". The rich become richer, and the poor still remain poor, and the gap between the rich and the poor grows to widen in labor market. With the economic development, the difference between the rich and the poor has become wider. And this state is continual, manifesting that the relatively poor working class lack enough 
resources, such as relationship in career, and resource network (human resource, information or technology resource). Therefore, the poverty in China now is manifested as the deprivation of resources and opportunities.

In many cities of developing countries, the most important cause of working poverty is the unequal distribution of opportunities, as well as the lack of social protection for the bottom of the residents (Guan, 2001). Historically, the economic reform and opening (1978) in China has de facto affected three cohorts so deeply that scores of them suffered higher risk into working poor: peasant-workers, laid-off workers, and female workers. They have their characteristics and professional career trajectories. To understand the conceptual working poor in mainland China, it is necessary to distinguish the main in-work poverty groups with their trajectory under different transitions and event histories, thereby to bridge poverty at individual level and historical changes in social structure.

\section{The Life Trajectory of Peasant-Workers Related to In-work Poverty}

Peasant-workers: Migration from rural to urban; transition from stability to flexibility; experiences from being secured to high risk into poverty (see Figure 1).

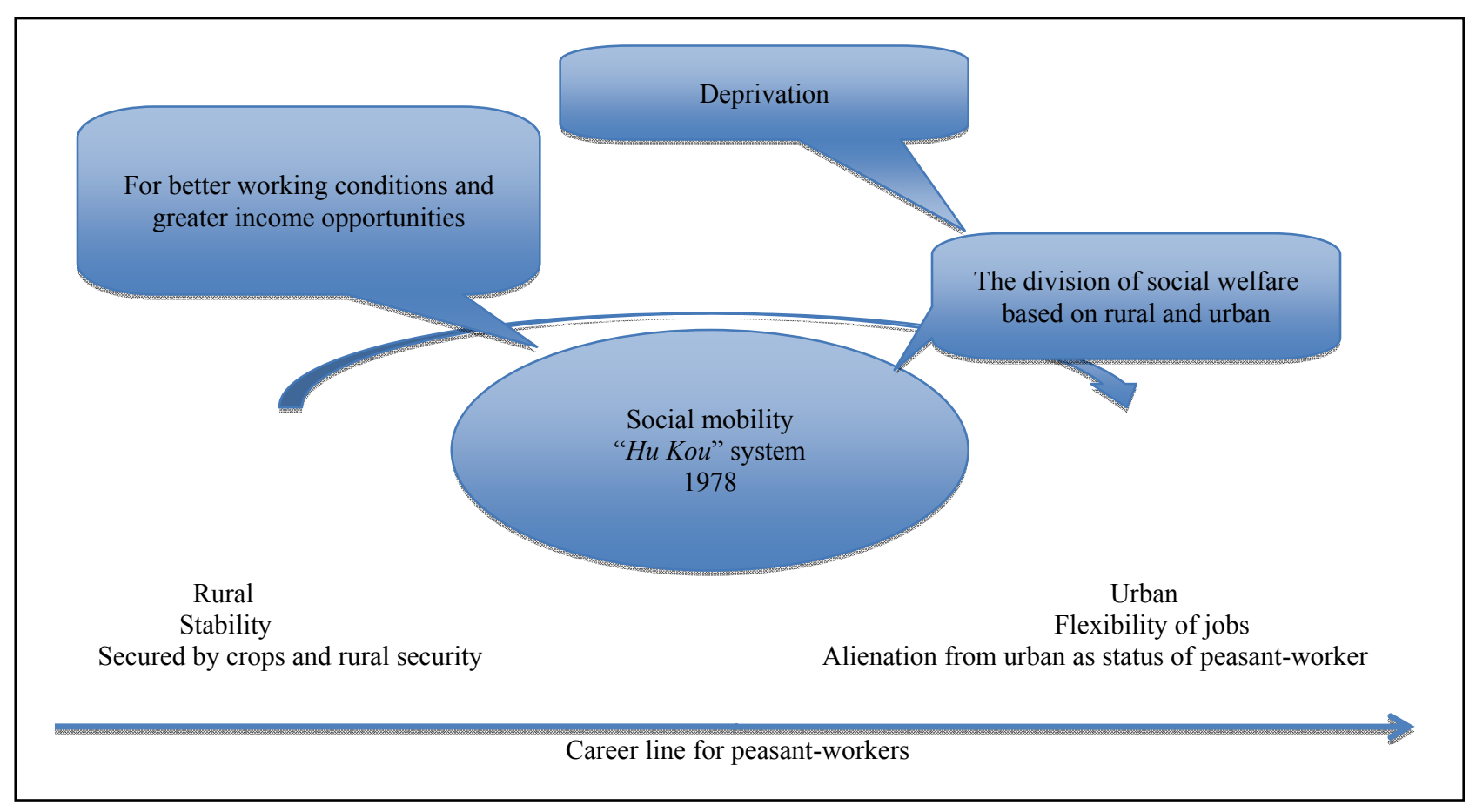

Figure 1. Career line for peasant-workers in mainland China.

\section{Event History: Social Mobility \& "Hu Kou" System}

Peasant-workers refer to migrant workers from rural to urban in mainland China.

(1) Behind this working group, the key words that should be discussed are the "mobility/flow" of work and the "Ни Kou" system. Since reform and opening up (1978), there were hundreds of millions of rural labors transferring from rural to urban to search for better working conditions and greater income opportunities.

(2) The "Ни Коu" system (Chinese registration system) makes such migration not so easy since 1970s, which also mainly led the disparity and gap of income between urban and rural areas. What is more, the "Hu Kou" system keeps close links between social welfare and citizen status (citizens in urban or in rural). 
What happened after above two history events? The story started from the difference of household registration for workers: Even though one could work and live in urban, his/her well-being or workfare still remains the primary standards in rural social security, thus leading equal work, not equal security/rights. On one hand, when the economic reform in early 1980s spread in the city, urban workers have increased substantially in real wages. While, in order to protect the urban workers from the rural worker's competition, there was still the rigid restriction for migration from rural. Since then, such restriction was loosed; rapid urban economic development has attracted a large number of migrant workers from countryside to city, which led to insufficient employment opportunities, the appearance of low-paid jobs, and the intension of housing and public facilities. What is more, according to a 2009 report from the World Bank, if the city's migrant workers are calculated in the rural population, there are nearly $99 \%$ of poverty population comes from China's rural areas. And if removing the migrant workers, there are still $90 \%$ of poverty populations who come from the rural areas (Canaves, 2009). Then, the poor conditions for rural labors did not significantly change, and even after two history events, these city's peasant-workers still keep rural household registration, which means that the status identities were farmers. Thus, comparing to city's citizens, they still have higher risk into poverty. In detail, under the flow of migrant workers and rapid economy reform, the social status for peasant-workers was changed, which was transitioned from peasants initially to migrant workers, and finally labors at the low-income levels in labor market. Before the cancellation of household registration system in 2016, most of them still hold the rural household registration, which means that most of them could not participate in a series of social insurance especially for urban workers/citizens. So, "deprivation" becomes one characteristic for migrant workers as working poor: the deprivation of the equal rights for choosing a job, enjoying the equal social rights and welfare like urban citizens.

All in all, at least from 1978 to 2015, the Chinese labor market was still in the process of modern economy transition; it is the co-existence of high job mobility and tighter registration system. The existence of this contradiction adds to the lack of corresponding social rights and welfare for migrant labors: They transfer from peasants to migrant labors, while still facing the deprivation of health, education, and some other social rights, thus adding to the two characteristics for them: deprivation and the division of social welfare between rural and urban.

\section{The Life Trajectory of Laid-off Workers Related to In-work Poverty}

Laid-off workers: Experiences from employment to lay-off; transition from state-owned enterprises to private enterprises; secured from employment in "iron rice bowl" to liberal employment under the flexibility trend of jobs (see Figure 2).

\section{Event History: Reform and Opening in 1970s}

Market economic reform and opening in labor market started in the last 1970s. Since its transformation to "socialist market economy", "iron rice bowl" has been broken down and China has the fastest growing economies during the last 40 years.

What happened since then? Initially, the emergence of poor conditions for labors was clearly spawned by reform of state-owned enterprises (as we called "restructuring" of state-owned enterprises) since late 1980s, which is under the goals of catching up with the economic level of developed countries.

\footnotetext{
${ }^{1}$ It means all working-age urban residents would be assigned jobs in state-owned or collective enterprises with various social benefits, including pensions, healthcare, and housing. These jobs were not only secure, but could be transferred to children of the workers.
} 


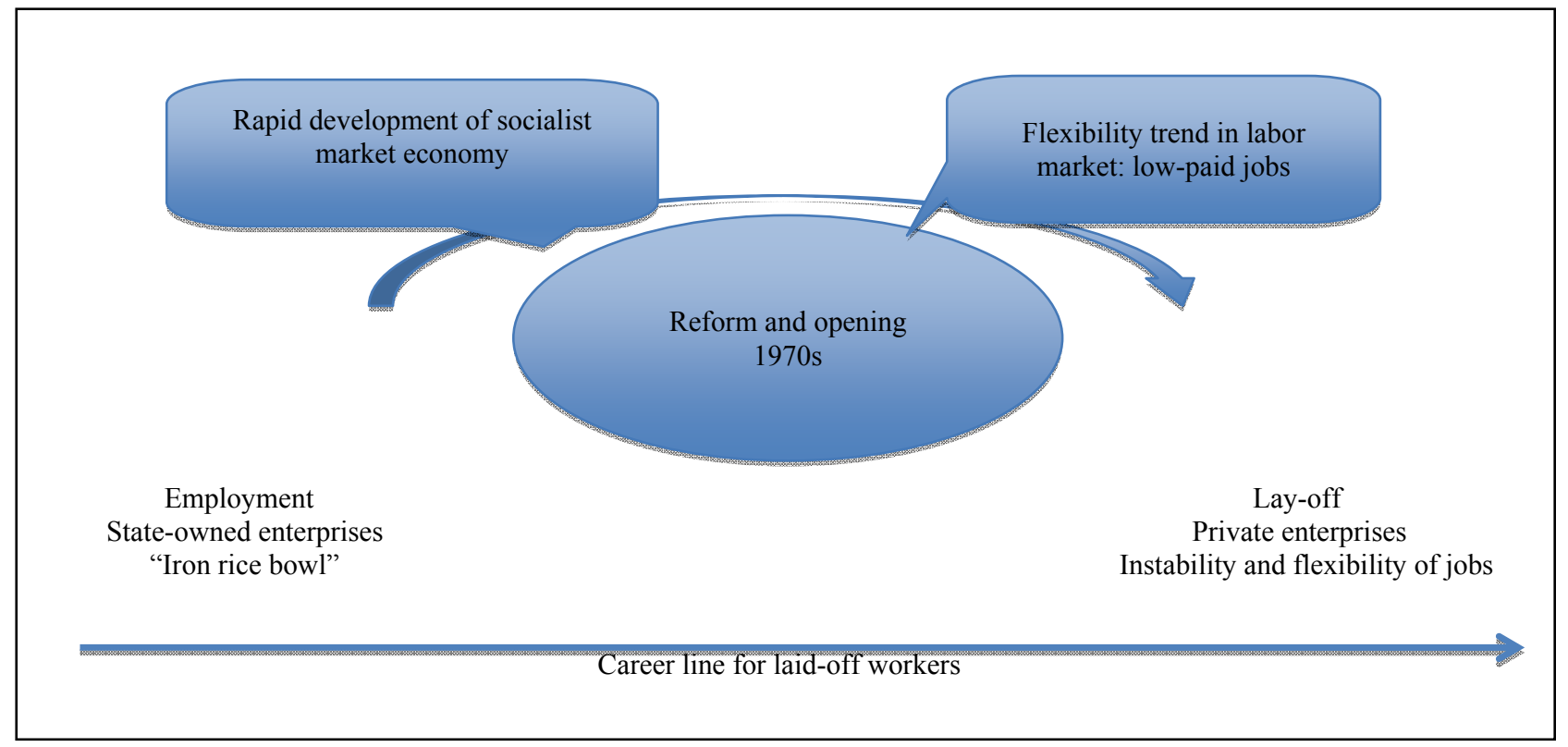

Figure 2. Career line for laid-off workers in mainland China.

On one hand, during the periods from 1990 to 1995 with the rapid development of socialist market economy, the income, bonus, and different kinds of benefits for citizens increased rapidly. Even though Chinese GDP per capita remains quite low which was still at 16\% of the OECD average in 2008 (which started to climb from a very low level historically), China's real GDP has grown faster which is above $8 \%$ since 2000 s.

On the other hand, the rapid economic growth indeed has a positive impact on employment growth, and this economic reform had a significant impact on evolution of China's labor market, resulting in crucial structural changes and labor shifts from traditional agriculture to modern industry and services. However, it also created large amounts of low jobs and indirectly led an instable and flexible trend for employment. In other words, it resulted in that numbers of state-owned enterprises broke down and caused the disappearance of tens of millions of jobs in urban areas. Millions of state-owned workers were laid-off in a short term; in order to cope with the problem of lay-off and need of high production in manufacturing, government put forward Reemployment Project and Unemployment Insurance, thus creating numbers of "low jobs" and taking in numbers of laid-off labors to work in relatively unstable and flexible jobs, and the conditions of these rejected labors were grim indeed. Therefore, since 1990s, China became the world's third largest exporter of manufacturing goods, and developed a pattern of specialization in low-skilled labor-intensive sectors. Then in-work poverty in China is contributed to the merging of large amounts of "low jobs" and rudimentary labor market provision net. Thus, low-paid jobs also became one of the characteristics for in-work poverty in mainland China, which is mainly manifested in laid-off workers' group.

Since economy transformation and opening, there remained large numbers of low-paid or low-skilled jobs in China and especially for some women with low education. For instance, from the perspective of employment structure, female employment level is still lower than that for male, and their average annual incomes are lower than that for male (even though "male and female equal pay for equal work" is a basic national policy of the country). In 2005, only $6.4 \%$ of women are working in the area of technology and management, while about $79.8 \%$ of women work as manual labors or non-management workers. According to the Report on Major 
Results of the Third Wave Survey on the Social Status of Women in China ${ }^{2}$, female (aged at 18-64) employment rate is $71.1 \%$ in 2011 ; among them, urban employment rate is $60.8 \%$ while the rural employment rate is $82.0 \%$. The female average annual income in urban and rural respectively is $67.3 \%$ and $56.0 \%$ of male average annual income in urban and rural. Therefore, under the economy reform and opening, the flexible trend of jobs has more influence on women.

\section{Conclusions and Discussion}

China's citizens have generally experienced a substantial rise in living standards, while not all working groups have benefited from such rapid and dynamic economic growth. It seems that widening levels of inequality and new forms of social risk have accompanied the increase of wealth into poverty, at least for the three cohorts. Then, what mainly caused working poor?

(1) As the characteristics of working poor, the deprivation of resources and opportunities for labors shapes poor conditions in multi-dimensions: Concerning the tension and tradeoff among the social, cultural, and economic aspects, which are among individual, work relations, and household levels; everything has its inner contradiction, so policy is no exception. State has its inevitable lag of policy; market is manifested as its self-interests, and the contradiction or conflict between a natural man and a social man is always a problem that humans face and discuss. Therefore, individual or household is easy to be shaped by state and market. Like women in mainland China, they could enter into labor market and work under the top-down political encouragement, while they also have the limited choices when facing the force to be laid-off during SOE (state-owned enterprises) reform in 1990s. The individual's choice in career lines is always limited and affected by a series of historical events at macro level.

(2) For the responsibility of state, the existed public policy for anti-poverty in China is to encourage people to participate in economic activities (push into labor market) and to create friendly employment environment. As public policy plays a very significant role in shaping the income distribution and labor market participation of various groups (Crettaz, 2010), the positive and obvious function of such social policy is to give the poor people opportunities to change their lives. But we should pay attention to the contradictoriness of the decision-making. The initial purpose of labor market is to maintain the operation of economic activities; especially since late 20th century, the hypothesis of "economic person" has become a modest explanation to explain "scientifically" all kinds of phenomena in the public domain. The successors of Smith made the hypothesis of economic person more and more utilitarian, reasonable, and formal, so the hypothesis lost its original ethics idea. The tension of state and labor market is manifested as the conflict of the lagging policy and self-interests in labor market. On one hand, because the rule of the state policy is trying to realize the justice of majority of people, but the set of rules of market economy does not play like that in accordance with the political intention, the lagged and mismatched welfare policies cannot easily adapt to the labor market transformation. The fundamental characteristics of labor market are self-interest, voluntariness, fairness, and competitiveness. The tension and contradiction among state and market is the difference of rules. So, the result of negotiation for state is to push the absolutely unemployed poor people into working poor. In fact, the intention of state, which alleviates poverty, is not successful in market operations, for example, like China now

\footnotetext{
2 The Third Wave Survey on the Social Status of Women in China is jointly launched and organized by the All-China Women's Federation (ACWF) and National Bureau of Statistics (NBS), and is a nationwide decennial survey following the first and second wave surveys conducted respectively in 1990 and 2000.
} 
(the policy encourages laid-off workers to employ in community or some "low jobs"). On the other hand, if market yields in this negotiation with state, which means under the background of strong state-control institutions, it will lose its economic dynamism and competitiveness. So it is easy to shape the market as state's willings, and it is easy to become a political tool in the struggling of state interests. And without the purpose of economic development, poverty is transformed from inequality in wealth gap to the widespread equality poverty. For example, we can look back to the socialist planning economy period in China, especially in Great Culture Revolution. Otherwise, human being has to control the contradiction between the natural and social aspects. On one hand, poverty is manifested as the unequivalence of rights and obligations, for example, equal work, not equal pay; the deprivation of rights into family caring... On the other hand, we are social humans, so we are easier to be shaped by the society, to be influenced by the public policy and market. In this negotiation, whether the state or market, we need to learn to balance their relationships, and explore how to wisely survive (see Figure 3).
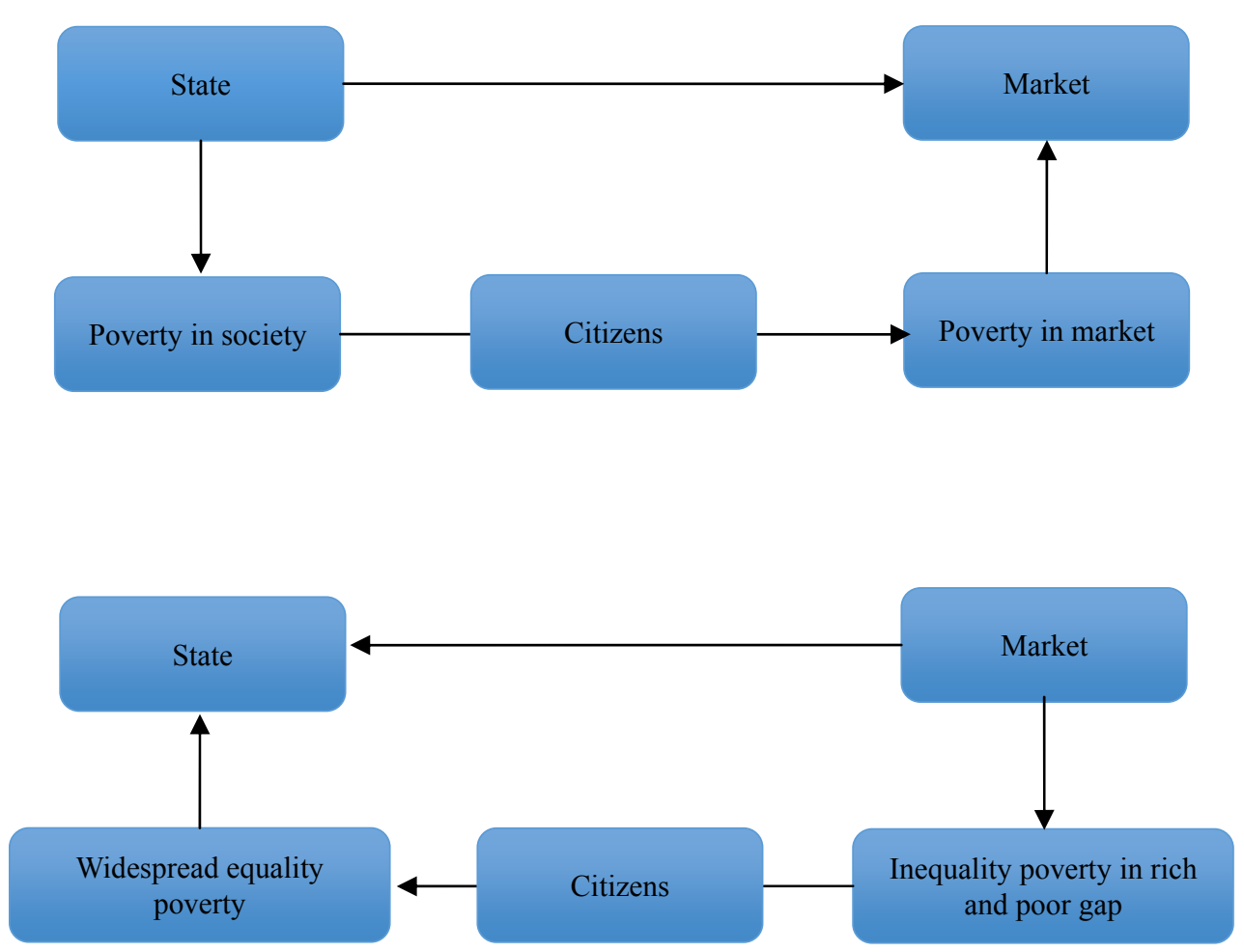

Figure 3. The negotiation among state, market, and individual.

(3) Working poor in China experienced from the period of "strong state" role (1949-1978) to the period of "strong market" role (1978-?). The poverty stemed from the widespread equality and absolute poverty before develops the poverty among workers in inequality in labor market nowadays. What the government to reform is trying to balance the relationship among state, individual, and market.

Therefore, although there is no "one-size-fits-all" policy mix, for alleviating such tension, both state and labor market should hold their cooperative roles and responsibilities for anti-poverty to overcome their own limitations: It is the responsibility for state to take on a set of strong policies to promote a generally higher 
education and relatively better social skills for workers within the three in-work poverty groups. Meanwhile, market should realize the task of active corresponding policies/strategies to support nonworking partners of poor workers.

\section{References}

Andress, H.-J., \& Lohmann, H. (Eds.). (2008). The working poor in Europe: Employment, poverty and globalisation. UK: Edward Elgar Publishing.

Berger, S., \& Harasty, C. (2002). World and regional employment prospects: Halving the world's working poor by 2010. Retrieved from http://www.oit.org/wcmsp5/groups/public/@ed_emp/@emp_elm/documents/publication/wcms_114249.pdf

Bruno, L., Jin, Y., \& Norris, D. (2009). Building career ladders for the working poor through literacy training. US Department of Labor, Employment and Training Administration. Retrieved from https://wdr.doleta.gov/research/FullText_Documents/ Building_Career_Ladders_for_the_Working_Poor_Through_Literacy_Training.pdf

Canaves, S. (2009). Facts about poverty in China challenge conventional wisdom. The Wall Street Journal. April 13, 2009.

Crettaz, E. (2010). Alleviating working poverty in postindustrial economies. Retrieved from https://serval.unil.ch/resource/serval: BIB_E6B51B41D085.P001/REF

Guan, X. P. (2001). Economy-Social transformation, globalization and China's rural poverty issue. Proceedings from Conference of Chinese Social Transformation, Renming University of China, Beijing, pp. 12-29.

Kim, M. (1998). The working poor: Lousy jobs or lazy workers? Journal of Economic Issues, 32(1), 65-78.

Marlier, E., Cantillon, B., Nolan, B., Van den Bosch, K., \& Van Rie, T. (2009). Developing and learning from measures of social inclusion in the European Union. In manuscript, Paris conference. Retrieved from http://media.leidenuniv.nl/legacy/timvan-rie---developing-and-learning-from-measures-of-social-inclusion-in-the-eu.pdf

Rowntree, B. S. (1902). A study of town life. UK: Macmillan.

Smith, A., Stenning, A., Rochovská, A., \& Świątek, D. (2008). The emergence of a working poor: Labour markets, neoliberalisation and diverse economies in post-socialist cities. Antipode, 40(2), 283-311.

Yao, J. P. (2011). Working poor in Chinese urban area: Problems development, group characteristic, and positive social policy. Social Security Studies, 1, 14. 